\title{
Treatment of wastewater resulted from sucrose, fructose and starch production by aerobic activated sludge process
}

\begin{abstract}
Main pollutants in wastewater, resulted from sucrose, fructose and starch industry are settlable matter, $\mathrm{SO}_{2}$, ammonia, $\mathrm{COD}$ and $\mathrm{BOD}_{5}$. Concerning $\mathrm{pH}$, temperature, oil and grease no problems encountered. In this investigation most of the organic pollutants will be removed by high rate aerobic activated sludge process, but some type of reverse osmosis (RO) is recommended for total dissolved solids or inorganic salts and chlorine removal. Chemical precipitation process is suitable for phosphorus removal. Anaerobic treatment reduces the organic pollutants above $90 \%$ and they are converted to biogas with very low to negative operating cost. The proposed treatment unit presents an effluent and low cost industrial wastewater treatment plant to meet the required effluent standards. Also detailed engineering design of the various components of proposed industrial wastewater treatment plant (IWWTP) is achieved. Characterizations of wastewater after treatment fulfill the requirements of governmental regulations so it can be reused industry as cooling water or in irrigation; also the resulted sludge can be used as fertilizer or animal fodder after minor treatment.
\end{abstract}

Keywords: aerobic \& anaerobic treatment, fructose syrup, glucose syrup, starch, wastewater treatment
Volume 3 Issue 5 - 2018

\author{
Mona A Abdel Fatah, Hawash SI \\ Department of Chemical Engineering and Pilot Plant, National \\ Research Centre, Egypt
}

\begin{abstract}
Correspondence: Mona A Abdel Fatah, Department of Chemical Engineering and Pilot Plant, National Research Centre, Egypt, Tel+0100040724I, Email monamin46@gmail.com
\end{abstract}

Received:September 18, 2018 | Published: November 21, 2018

\section{Introduction}

Starch which is naturally occurring polymer has numerous industrial applications, as well as food, cosmetic, pharmaceutical, medicine, chemical, papermaking, textile, detergents and other industrial sectors as one of the main raw material. ${ }^{1-3}$ Sucrose or table sugar is made out of sugar cane and sugar beet, neglecting the small part produced from sweet sorghum and sugar palm. ${ }^{4}$ However, there are many other sweeteners that are used for our food production. Two examples are High Fructose Maize Syrups and artificial or high intense sweeteners. ${ }^{1}$ Starch, glucose and fructose syrup in the US and in major other parts of the world are mainly produced from maize as raw material. ${ }^{5}$ Wastewater generated from starch processing has to be treated because it represents an environmental challenge due to the large chemical oxygen demand (COD) of the wastewater, generally ranging between 6 and $10 \mathrm{~g} / \mathrm{L} \cdot{ }^{6-9}$ Removing more than $80 \%$ of COD after 3 days using Filamentous Fungi for treating starch plant wastewater was investigated. ${ }^{10}$

Usually settlable solids recovered by settling or clarification are reused as animals feed additives but without using any flocculants or coagulant aids in the decantation process. ${ }^{8}$ Removal of suspended solids from industrial, domestic, building material and livestock wastewater was achieved using bio-flocculent as a new water treatment agent. ${ }^{8,11-13}$ Bio-flock technology does not need any increasing in basic natural resources of water and land, also it minimize damage to the environment and support social sustainability \& economic. ${ }^{14-18}$ Removal rates of chemical oxygen demand (COD), total ammonia nitrogen (TAN), and suspended solids (SS) in aquaculture wastewater reached $64,63.61$, and $83.8 \%$, respectively using a bio-flocculentProducing Bacterium Bacillus mega-terium. ${ }^{19}$ Reduction the environmental footprint from water and waste streams, by maximizing reuse of water, by turning waste to value, and by minimizing energy consumption and waste is the main objective of this investigation. Wastewater and sludge treatment help production of clean effluent for discharge or water reuse, recover heat and reduce the amount of sludge for disposal.

\section{Experimental}

Treated wastewater is produced from two streams which are mixed in a sump tank then passed through rotary drum screen $0.5 \mathrm{~mm}$ mesh to remove big suspended particles. After screening the effluent flows to a conditioning tank in which $\mathrm{FeCl} 3$ and micronutrients $(\mathrm{Co}, \mathrm{Cu}$, $\mathrm{Mo}$ and $\mathrm{Ni}$ ) are dosed. From there, the wastewater is transferred to anaerobic treatment step in two bio-bed reactors. Then wastewater was subjected to aeration then to settling processes. Finally evolved biogases are collected for various purposes and sludge produced is dewatered to disposal.

\section{Technological Considerations}

The main components of the treatment plant are similar to earlier designs in previous investigations ${ }^{20-22}$ but the essential difference lies in using two bio-bed reactors due to the high load of BOD. So design is based mainly on solids removal and buffering, using a conditioning tank, an-aerobic high rate treatment with a bio-bed reactor and final polishing in an aerobic type of activated sludge plant to meet the required discharge limits and evolved biogas purification from $\mathrm{H}_{2} \mathrm{~S}$.

\section{Proposed treatment unit}

The proposed treatment plant consists mainly of:

a) Rotary drum screen $0.5 \mathrm{~mm}$ mesh.

b) Buffering tank, with 6hours hydraulic retention time, to level out the main fluctuations inflow and composition. 
c) Conditioning tank to condition the feed for the bio-bed reactor.

d) Two bio-bed reactors equipped with all required internals (influent distribution system and three phase separators (settlers).

e) Anaerobic sludge holding tank (for granular anaerobic sludge).

f) Aerobic polishing tank (high loaded activated sludge type) to meet the discharge limits.

g) Sludge dewatering facilities.

The above components are provided with mixers, pumps of different types, blowers, centrifuge, air distributer, $\mathrm{pH} \&$ temperature measurement instruments, dosing devices and control system.

\section{Design basis}

Taking in consideration industrial effluent characteristics design starting points are:

- Water flow $-3960 \mathrm{~m}^{3} /$ day

- COD load-8000mg/1

- BOD load-4624mg/1

- Sludge load $-0.5 \mathrm{~kg} \mathrm{BOD} / \mathrm{m}^{3}$

- Sludge concentration- $3 \mathrm{~kg}$ sludge $/ \mathrm{m}^{3}$

- Sludge productionv0.6kg sludge $/ \mathrm{kg}$ BOD removed

- Sludge return flow- $100 \%$

- Sludge return capacity- $165 \mathrm{~m}^{3} / \mathrm{hr}$

- Surplus sludge production-1,560kg sludge/day

- Final Surface load of clarifier- $1 \mathrm{~m} / \mathrm{hr}$

- Aeration capacity required-300 $\mathrm{kg} \mathrm{O}_{2} / \mathrm{hr}$

- Total air requirement of $-5.500 \mathrm{Nm}^{3} / \mathrm{hr}$

\section{Results \& discussion}

Experimental data from laboratory bench scale and results of analyses of wastewater for the mixed two effluent streams were the basis of the design of the industrial wastewater treatment plant (IWWTP).

\section{Treatment process description}

The design is based on solids removal and buffering, use of a conditioning tank, anaerobic high rate treatment with a BIOBED reactor and final polishing in an aerobic type of activated sludge plant to meet the requirements of governmental Egyptian regulations for discharging limits.

\section{Principal units of IWWTP}

Detailed engineering design of the various components of proposed IWWTP is given in the following paragraphs.

Effluent pumping station, solids removal (screens), buffer tank and feed pumps to the conditioning tank

The Buffer tank is designed to receive the industrial wastewater coming from the lift pump station. It is designed with the suitable capacity, completed with the transfer pumps and the accessories. It is assumed that the factory effluent is supplied at sufficient pressure in the vicinity of the conditioning tank. Some valves/piping will be required to connect a by-pass to the aerobic plant and sampling facilities. Conditioning tank must be provided with a mixer, a splatter box to split anaerobic effluent and anaerobic recycling, facilities for dosing chemicals and micronutrients $(\mathrm{Co}, \mathrm{Cu}, \mathrm{Mo}$ and $\mathrm{Ni}$ ) fed to the bio-bed reactor. The Conditioning tank operate under normal operating pressure in the gas/head space $0.05 \mathrm{bar} /$ design pressure 0.075 bars)-Biogas from the reactor will be extracted via (the gasspace) of the conditioning tank.

\section{Chemicals and micronutrients dosing facilities}

Caustic soda, $\mathrm{FeCl}_{3}$ and micronutrients dosing facilities are to be designed for adding $\mathrm{Fe}$, and micronutrients (if required, $\mathrm{Co}, \mathrm{Cu}$, $\mathrm{Mo}$ and $\mathrm{Ni}$ ) as a nutrient (in the feed line to the reactor. Storage tank volumes for used chemicals depend on available (minimum) bulk supply volume and were supplied dosing pumps regulated by timer. Two (one duty, one standby) centrifugal pumps with a capacity of $252 \mathrm{~m}^{3} / \mathrm{hr}$ each will be required to feed the conditioned wastewater from the conditioning tank to the BIOBED reactor.

\section{BIOBED reactor feed pump}

Two centrifugal pumps (one duty, one standby) required to feed the conditioned wastewater from the conditioning tank to the BIOBED reactor.

\section{BIOBED reactors}

The BIOBED process is a cross-breeding between the UASB process and the FB (Fluid Bed) process. The Biomass in the reactor is present in a granular form. These granules resemble the granules that occur in the reactor. It is in fact possible to inoculate a BIOBED reactor with granular sludge that originates from the reactor. Due to the conditions imposed on the sludge with respect to liquid and gas up flow velocities a granular sludge develops which has excellent settling properties $(35-80 \mathrm{~m} / \mathrm{h})$ and in some cases a higher specific activity than in the UASB concept. In order to create optimal conditions for the growth of the granular sludge a mild hydraulic regime near the outlet nozzles in the distribution system is of special importance. This is more or less in contradiction with the need for good flow distribution and the minimizing of dead space. However, due to a high hydraulic throughput a good compromise was found. Due to the high up flow velocities for water and gas (can be both as high as $6 \mathrm{~m} / \mathrm{h}$ ) the necessity arises to perform an excellent phase separation for water-biogas and sludge in the top of the reactor and Figure 1 illustrates a schematic drawing of the used BIOBED reactor.

\section{Biogas Handling}

Biogas produced contained approximately $75-80 \%$ of $\mathrm{CH}_{4}, \mathrm{H}_{2} \mathrm{~S}$ of $0.5 \%$ and average caloric value of $32 \mathrm{MJ} / \mathrm{m}^{3}$. The biogas production from the reactor will be measured and released to prevent overloading of the plant (interlock with the conditioning tank feed pumps).

\section{Anaerobic sludge holding tank}

This tank has adequate capacity to store organic biomass sufficient to replace the content of sludge in the reactor in emergency cases. This tank is supplied with a sludge pump to transfer the sludge from the reactor to the anaerobic sludge holding tank and vice versa. 


\section{Aeration tank}

Aerobic biological treatment contact between the effluent from anaerobic plant and the bacterial growth was achieved for removal of organic materials from the anaerobic effluent. Mixing and aeration are achieved by diffusing air from air blowers. The tank is a channel shape with horizontal helical flow, due to the diffused air effect. Sludge from the final settling tanks will be recycled by a submersible and/or air lift pump to the front inlet area of the aeration tank. The following Figure 2 shows the pipelines and the PFD of the treatment plant.

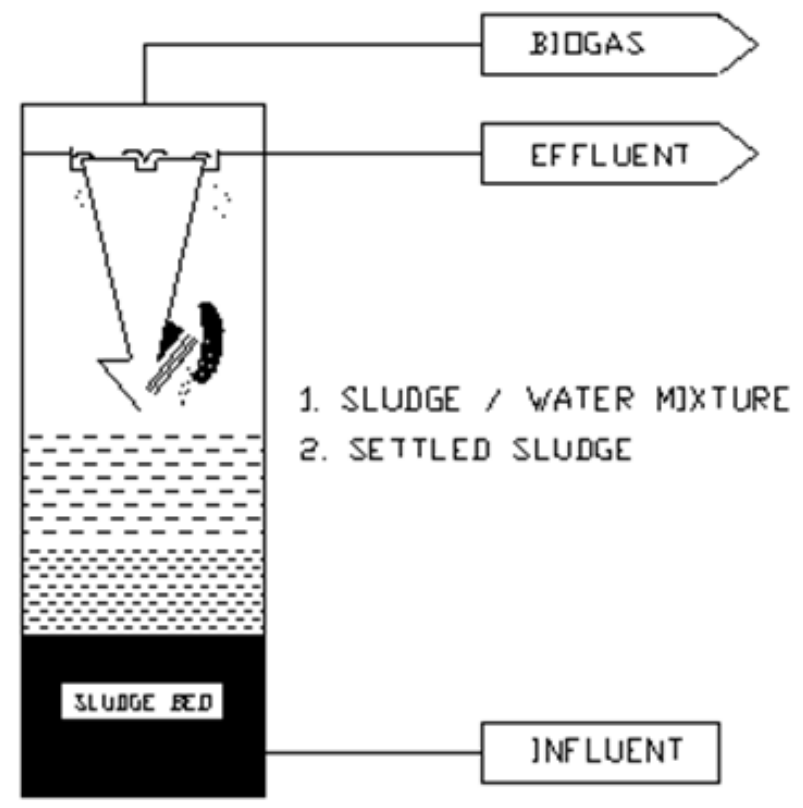

Figure I Drawing of a BIOBED reactor.

\section{Settling tank}

This tank is designed to remove the stabilized organic matters from aeration tank using the mechanical properties of the suspended solids. The tank is circular in shape with radial flow from the control stilling chamber to the perimeter. The inlet pipe enters the stilling chamber and the outlet is a perimeter overflow weir. The tank bottom is of conical base inclined by 45 degree and is equipped with outlet pipes for sludge removal using centrifugal pumps.

\section{$\mathrm{FeSO}_{4}$ holding tank}

It is a cylindrical tank made of high density polyethylene (HDPE) for ferrous sulphate storage.

\section{Sludge tank}

This tank is rectangular in shape and it is equipped with air diffusers and receives sludge from the final settling tank for sludge storage period. In this unit additional more sludge stabilization was achieved to reduce its volume to $50 \%$ of the influent.

\section{Sludge thickening}

In this step sludge was dewatered thickening then centrifuged with polymer conditioning to $15 \%$.

\section{Process performance and evaluation}

The results of the final analyzes show the quality of the treated water and the good performance of the treatment process as shown in the following results which enable us to reuse treated water according to the Egyptian environmental regulations and laws:
a) $\mathrm{pH}$
6-9
b) $\mathrm{COD}$
$60 \mathrm{mg} / 1$
c) $\mathrm{BOD}$
$20 \mathrm{mg} / 1$
d) TSS
$20 \mathrm{mg} / 1$
e) O\&G5
$\mathrm{mg} / \mathrm{l}$ 


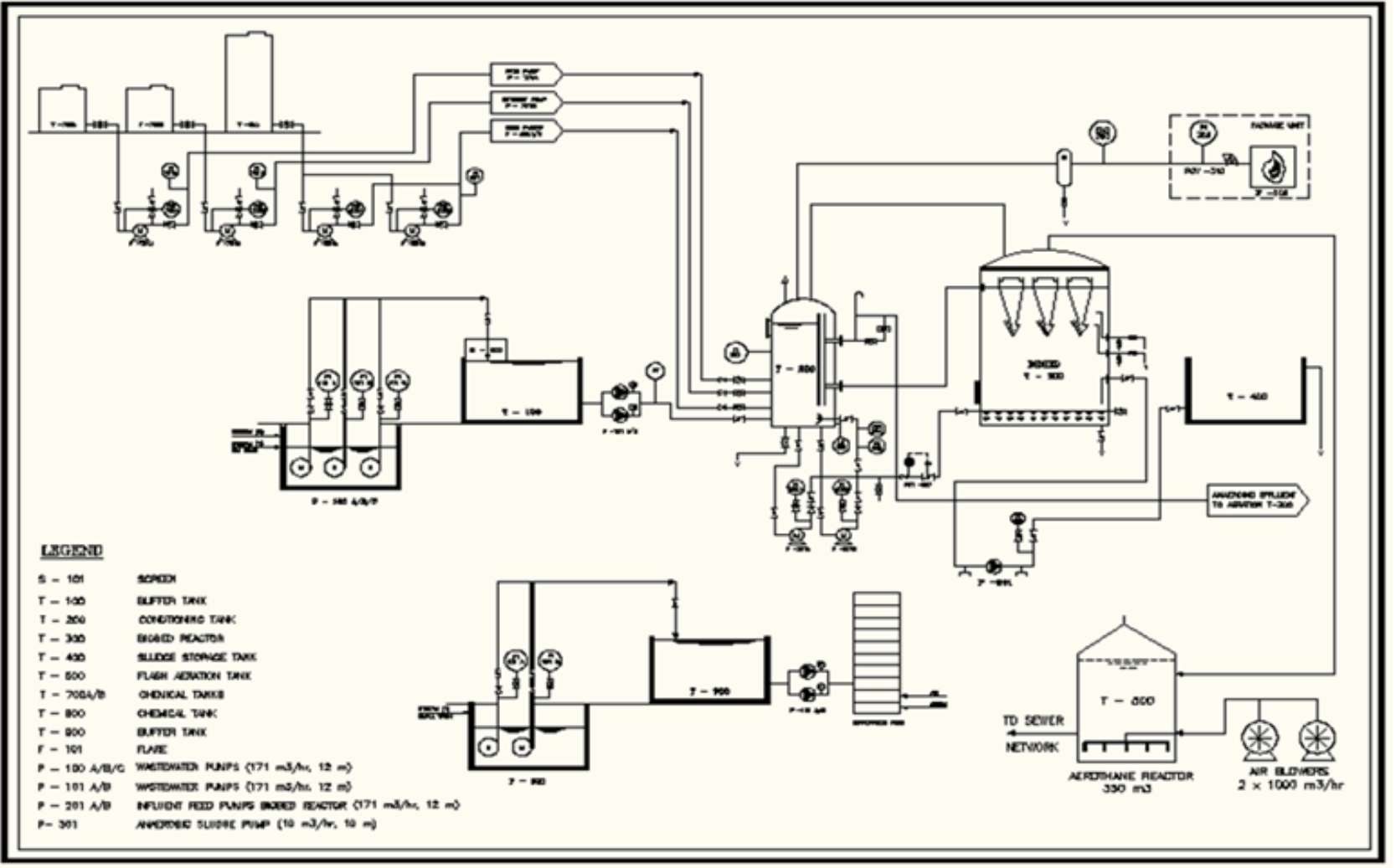

Figure 2 shows the pipelines and the PFD of the treatment plant.

\section{Conclusion}

The recommended treatment process of wastewater effluent is suitable with high performance because:

a) The organic compounds present in the wastewater are largely degraded by anaerobic sludge treatment and converted to biogas which can be used as fuel for other purposes in the plant.

b) The anaerobic system reduces the organic pollutants in wastewater by above $90 \%$ with moderate investment and very low to negative operating cost.

c) The specifications of treated wastewater fulfill the requirements of governmental regulations so it can be reused as coolant or in irrigation of non edible crops like wood trees.

d) Whether anaerobic system is economical depends on the amount of biogas produced from the system.

\section{Acknowledgments}

None.

\section{Conflicts of interest}

The author declares that there is no conflicts of interest.

\section{References}

1. Radley JA. Industrial Uses of Starch and its Derivatives.1st ed. Essex: Applied Science Publishers LTD; 1976. 268 p.

2. Ahmadi Abhari S, Woortman AJJ, Hamer RJ, et al. Rheological properties of wheat starch influenced by amyloselysophosphatidylcholine complexation at different gelation phases. Carbohyd Polym. 2015;122:197-201.

3. Chen Yong, et al. Starch and starch sugar wastewater treatment technology scheme and operation monitoring. Biotechnology BTAIJ. 2014;10(19): 5 p.

4. Wolter Scholten. The water footprint of sugar and sugar-based ethanol. University of Twente, Netherlands: Enschede; 2009. 148 p.

5. Mona A Abdel Fatah HO, Sherif, Hawash SI. Investigation on Wastewater Treatment of Maize Processing Effluent. International Journal of Scientific \& Engineering Research. 2015;6(7):1-5.

6. Pu SY, Qin LL, Che JP, et al. Preparation and application of a novel bioflocculant by two strains of Rhizopus sp. using potato starch wastewater as nutrilite. Bioresour Technol. 2014;162:184-191.

7. Yu D, Li C, Wang L, et al. Multiple effects of trace elements on methanogenesis in a two-phase anaerobic membrane bioreactor treating starch wastewater. Appl Microbiol Biotechnol. 2016;100(15):6631-6642.

8. Deng S, Bai R, Hu X, et al. Characteristics of a bioflocculant produced by Bacillus mucilaginosus and its use in starch wastewater treatment. App Microbiol Biotechnol. 2003;60(5):588-593. 
9. Nasr M, Tawfik A, Suzuki M, et al. Mathematical modeling of biohydrogen production from starch wastewater via up-flow anaerobic staged reactor. Desalin Water Treat. 2015;54(1):50-58.

10. Pedro F Souza Filho, Akram Zamani, Mohammad J Taherzadeh. Edible Protein Production by Filamentous Fungi using starch plant wastewater. Waste and Biomass Valorization.2018;1-10.

11. Yan S, Wang N, Chen Z, et al. Genes encoding the production of extracellular polysaccharide bioflocculant are clustered on a 30-kb DNA segment in Bacillus licheniformis. Functional and Integrative Genomics. 2013;13(4):425-434.

12. Peng L, Yang CP, Zeng GM, et al. Characterization and application of bioflocculant prepared by Rhodococcus erythropolis using sludge and livestock wastewater as cheap culture media. Applied Microbiology and Biotechnology. 2014;98(15):6847-6858.

13. Giri SS, Harshiny M, Sen SS, et al. Production and characterization of a thermostable bioflocculant from Bacillus subtilis F9, isolated from wastewater sludge. Ecotoxicology and Environmental Safety. 2015;121:45-50.

14. Avnimelech Y. Feeding with microbial flocs by tilapia in minimal discharge bioflocs technology ponds. Aquaculture. 2007;264(1-4):140-147.

15. Crab R, Kochva M, Verstraete W, et al. Bioflocs technology application in over-wintering of tilapia. Aquacultural Engineering. 2009;40(3):105-112.
16. Stokstad E. Down on the shrimp farm. Science. 2010;328(5985):1504 1505 .

17. Crab R, Defoirdt T, Bossier P, et al. Bioflocs technology in aquaculture: beneficial effects and future challenges. Aquaculture. 2012;356-357:351356.

18. Zhao $\mathrm{Z}, \mathrm{Xu} \mathrm{Q}$, Luo $\mathrm{L}$, et al. Effect of feed $\mathrm{C} / \mathrm{N}$ ratio promoted bioflocs on water quality and production performance of bottom and filter feeder carp in minimum water exchanged pond poly culture system. Aquaculture. 2014;434(20):442-448.

19. Liang Luo, Zhigang Zhao, Xiaoli Huang, et al. Isolation, Identification, and Optimization of Culture Conditions of a Bioflocculant-Producing Bacterium Bacillus megaterium SP1 and Its Application in Aquaculture Wastewater Treatment. BioMed Research International. 2016. 9 p.

20. Hernández Morales MR. Technical-economical Evaluation for the Installation of a Wastewater Treatment Plant for a Nixtamalized Corn Doughs and Meals Factory. Mexico DF: 2005.

21. Durán de Bazúa SA, Sánchez Tovar MR, Hernández Morales, et al. Use of Anaerobic-Aerobic Treatment Systems for Maize Processing Installations. Applied Microbiology in Action C. 2007;3-12.

22. Shirish H Sonawane, Pydi Setty Y, Bala Narsaiah T, et al. Innovative Technologies for the Treatment of Industrial Wastewater. USA: Apple Academic Press; 2009. 320 p. 